\title{
ISLAM DAN KOSMOPOLITANISME BUDAYA
}

\author{
Hamadi B. Husain*
}

\begin{abstract}
A bstract: The M uslim ummah have been dragged into the global culture and have to accept the consequences that emerge thereof. To a certain degree, Muslims were deluded by this global culture and were -as a result- shackled into the seemingly irresolvable problems such as the problem of academic objectivity, the ulama-intellectual dichotomy, identity, terrorism, the so-called minor-major paradigm, and the problem of structural poverty. These problems are interdependent and require an all-embracing solution to resolve them. This paper argues that to speak of a solution on the one hand, and to set up the futuristic strategies to deal with those problems on the other, Muslims should first of all build a solid identity. Four steps are required to build this solid identity. (1) Adhering to the Qur' anic morality as the very foundation for Muslim's way of life. (2) Appropriating to the maximum the human and natural resources available to the Muslims, which would certainly require them to produce the competent scientists, engineers and so on. (3) Applying the rules of syari'ah to all aspects of Muslim's life by first of all gaining a proper understanding about the true teaching of Islam and the real spirit that underlies it. (4) Establishing and maintaining international relationships with foreign countries as well as with other cultures and civilizations. The implication of Islam being a religion of compassion is that it should be builtupon understanding and tolerance. Islam advocates the principle of mutual interest and is willing to achieve a better future for all human being.
\end{abstract}

Keywords: cosmopolitanism, future, tolerance, compassion

\section{Pendahuluan}

Dalam diskursus Islam dan Pembangunan, analogi Islam dengan Kemajuan begitu lekat, sama lekatnya antara kata Islam dengan Keterbelakangan (Umat). Kedekatan kata itu bermakna seakan-akan antara Islam dan Kemajuan terdapat hubungan saling membutuhkan. Artinya, tanpa kemajuan, Islam takkan mampu bertahan. Begitupun sebaliknya, tanpa Islam, kemajuan yang dicapai bisa jadi tanpa makna. Sama halnya antara kata Islam dan Keterbelakangan, merupakan dua gabungan kata yang hampir tak mungkin dipisah. Seakan menggambarkan fakta tentang problematika U mat Islam yang terus menggelayut hingga saat ini. Dan suka atau tidak begitulah potret peradaban Islam dewasa ini.

Di sisi lain, peradaban Barat dengan perkembangan sains dan teknologi nya semakin hari semakin menyilaukan mata; yang menawarkan berbagai kemajuan dan kemodernan, dan peningkatan kualitas hidup serta kesejahteraan masyarakat. Suatu fase yang sangat diimpiimpikan umat Islam di berbagai belahan dunia yang umumnya masih berkubang dalam kemiskinan dan keterpurukan.

Menyikapi kondisi ini, para intelektual Islam tentu tidak tinggal diam. Bahkan sejak masa berakhirnya Perang Dunia ke-2, para tokoh-tokoh Islam terkemuka dunia telah lantang bersuara untuk kembali mengangkat Islam dan umatnya pada kejayaannya seperti yang pernah dicapai 8 abad silam. Ratusan bahkan jutaan tulisan telah dibukukan, diurai dalam banyak makalah dan artikel-artikel ilmiah, diperbincangkan secara kritis dalam forum-forum seminar, simposium

\footnotetext{
* Fakultas U shuluddin IAIN Sunan Ampel Surabaya.
} 
dan sejumlah Konferensi-konferensi Tingkat Tinggi antar negara, yang kesemuanya berisikan tentang urgensi kebangkitan umat Islam dari keterpurukan untuk menggapai kemajuan dan martabat.

Namun, semua upaya yang telah dilakukan selama ini terasa muspra, ketika melihat fenomena sebagian besar negara berpenduduk Islam di berbagai belahan dunia masih terkungkung dalam jerat kemiskinan dan keterbelakangan; Rendahnya kualitas hidup, tingginya angka kriminalitas, minimnya kualitas pendidikan, seakan melengkapi penderitaan umat Islam. Maka munculah pertanyaan-pertanyaan mendasar seperti; Mampukah umat Islam keluar dari keterpurukan ini? Masih berfungsikah nilai-nilai dasar Islam untuk menopang peradaban umatnya? Ataukah justru harus diganti dengan nilai-nilai baru yang relevan sesuai dengan denyut nadi perkembangan zaman?

J awaban dari pertanyaan-pertanyaan di atas sangat beragam. Dari yang tradisional sampai yang modern. Dari yang paling fundamental sampai yang liberal (radikal). Solusi paling ekstrem yang ditawarkan para tradisionalis adalah dengan merujuk pada hasil ijtihad ulama dahulu yang cenderung dianggap absolut. Cara ini diklaim sebagai satu-satunya jalan kebenaran atau bahkan menjadi standar kebenaran itu sendiri. Adapun perubahan-perubahan yang dibawa oleh kemajuan ilmu pengetahuan dan teknologi dicap sebagai bid'ah. ${ }^{1}$

Sementara solusi paling radikal (liberal) yang ditawarkan modernis-liberalis adalah justru dengan menawarkan segala sesuatu yang berasal dari Barat, mulai dari model pemikirannya, sampai pada 'produk' pemikiran Barat. $\mathrm{H}$ al semata-mata hanya ingin melanjutkan tradisi Barat yang rasionalis, sekuler, liberal dan tampak terlalu jauh dari alam pikiran rakyat. ${ }^{2}$ Begitu liberalnya, bahkan sampai yang mengatakan, kini rukun Iman kita menjadi "tujuh" yaitu percaya kepada Amerka Serikat, sebab all American is exelences. ${ }^{3}$ Meskipun bersumber dari Barat, kalangan pemikiran ini mengklaim tetap mampu memelihara nilai-nilai keislaman yang universal, yaitu nilai-nilai yang lebih menitik-beratkan pada esensi keberagaman dan bukan pada simbolsimbol dan verbalisme beragama ${ }^{4}$. Demikian Tawaran ini dianggap sangat relevan jika umat Islam benar-benar ingin maju dan berkembang sesuai dengan denyut perkembangan zaman. ${ }^{5}$

\section{Problematika Umat Islam}

Hemat kami, Islam dan umatnya kini telah masuk kedalam jebakan budaya global yang membuatnya tak mungkin keluar atau niscaya menerimanya, meskipun tak pernah dikehendaki. A kibat keterjebakan ini, maka problematika umat datang silih berganti seakan tak kunjung usai, yakni seputar; Problem obyektif akademik, Problem Gap Ulama-Intelektual, Problem

\footnotetext{
${ }^{1}$ Harun Nasution \& Azyumardi Azra (ed.), Perkembangan M odern dalam Islam (J akarta: O bor, 1985), 15

2 Mohammed Arkoun, Religion et societe d'apres I'example de I'Islam, Studi Islamica ( Paris) dalam J ohan Hendrik Meuleman (ed),Tradisi, kemodernan, dan Modernisme.

${ }^{3}$ Kritik ini disampaikan oleh Timabalan Menteri Penerangan Malaysia Ybhg. Dato Ahmad Zahid Hamidi, dalam ucap Tama dan Peresmian Seminar antar Bangsa, di Universiti Kebangsaan Malaysia, 6 Agustus tahun 2007.

${ }^{4}$ Charles Kurzman (ed), Wacana Islam Liberal, pemikiran Islam Kontemporer tentang Isu-isu Global (J akarta: Paramadina, 2001 ). Lihat juga Leonard B inder, Islam Liberal (Yogyakarta: Pustaka Pelajar, 2001) atau tersebar pada sejumlah tulisan di site www.islamlib.com.

${ }^{5}$ Fazlur Rahman, Islam: Challenges \& Opportunities, dalam Harun Nasution \& Azyumardi Azra (ed.), Perkembangan Modern dalam Islam (J akarta: Obor, 1985), 34.
} 
kepribadian, Problem Terorisme, Problem paradigma mayor-minor, dan Problem Kemiskinan struktural, yang kesemuanya bertalian dan saling pengaruh satu dengan lainnya.

a. Obyektif Akademis

Naquib al-Attas dalam "Risalah Untuk Kaum Muslimin" yang selesai ditulisnya pada awal tahun 1973, menyatakan:

"Kini sudah jelas bagi kita kaum Muslimin bahwa akar masalah yang sedang kita hadapi ini sesungguhnya terletak pada masalah di sekitar pengertian ilmu. Akal pikiran kita telah diliputi oleh masalah sifat dan tujuan ilmu yang salah... orang Islam telah terpedaya dan secara tidak sadar telah menerima pengertian ilmu yang dianggap sama dengan pengertian kebudayaan Barat. M ereka telah memberi pengertian ilmu sesuai dengan sifat dan tabiat kepribadian mereka. Sedangkan makna ilmu itu berbeda-beda sesuai dengan agama dan kebudayaan berdasarkan pandangan hidup masing-masing. Islam pun mempunyai pandangan hidup tersendiri yang mencerminkan sifat dan tabiat kepribadiannya sendiri yang berbeda dari pandangan hidup agama dan kebudayaan lain".

Di sini al-Attas menyadari betul bahwa peradaban Islam adalah peradaban yang memperhatikan ilmu pengetahuan dan bahkan dibangun atas dasar ilmu pengetahuan. Sedangkan ilmu pengetahuan Islam dan pandangan hidup Islam berkaitan sangat erat, sebagaimana yang diungkapkan dalam al-Qur'an (QS. 96:5)

“... (Allah) mengajarkan manusia segala apa yang belum ia ketahui."

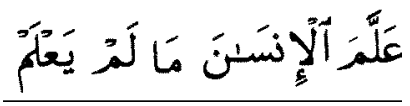

Ayat ini jelas menggambarkan perbedaan yang signifikan antara ilmu dalam paradigma Islam dengan ilmu Barat, bahwa ilmu yang kita miliki adalah ilmu yang diajarkan oleh Allah, sementara ilmu dalam pandangan manusia Barat adalah ilmu yang dicari oleh manusia itu sendiri. ${ }^{6}$ Paradigma ini pula yang mengindikasikan keterjagaan seorang ilmuwan muslim dari sikap arogansi dalam dunia ilmu pengetahuan.

Faktanya, banyak negara Islam (atau yang mayoritas berpenduduk muslim) di berbagai belahan dunia menganut faham kemodernan ala Barat, yang mewarnai kebijakan-kebijakan perekonomian, politik dan pembangunan negaranya, bahkan dalam penanggulangan kemiskinan umat Islam secara umum. Antara lain, negara-negara penganut teori ekonomimoneter yang bertumpu pada pinjaman modal negara-negara maju yang tergabung dalam International Monetery Fund (IMF). Atau kebijakan-kebijakan pembangunan yang bertumpu pada pasar yang didominasi kaum Kapitalis Barat. J uga kebijakan penanggulangan kemiskinan yang masih berpijak pada penanggulangan fisik dan bukan tertuju pada pemberdayaan masyarakat miskin itu sendiri. Mengapa banyak negara muslim menganut teori-teori tersebut, dikarenakan kesalahan cara pandang mereka yang terlalu "silau" pada keilmuan dan pemikiran-pemikiran Barat, sementara khazanah pemikiran Islam sendiri mungkin dipandang tak lagi relevan dengan perkembangan zaman.

J adi jelaslah bahwa tantangan umat Islam dewasa ini semakin kompleks dan lebih

${ }^{6}$ Disampaikan oleh Pengarah Institut Islam H adhari Prof. Dr. Muhammad Yusof Haji Othman, pada pembukaan Seminar antar Bangsa, Universiti Kebangsaan Malaysia (UKM), tahun 2007. 
prinsipil, tidak hanya seputar agresi militer, instabilitias politik, keterpurukan ekonomi, kerusakan moralitas masyarakat dan pemimpin, namun bersumber pada kesalahan paradigma umat Islam terhadap ilmu, yang terlalu keBarat-baratan yang sarat dengan nilai-nilai materialisme dan sekularisme.

\section{b. Gap Ulama-Intelektual}

Dampak dari pemisahan urusan-urusan keduniawian dan urusan akhiratsecara langsung mempengaruhi cara pandang Barat yang dikotomis terhadap ilmu pengetahuan. IImu kemudian dibagi kedalam dua kutub yang berbeda. Yakni ilmu-ilmu yang sifatnya duniawi, dan ilmu-ilmu yang sifatnya ukhrawi. ${ }^{7}$

Dikotomi ini selanjutnya dapat dijelaskan lebih rinci kedalam dua aspek; (1) Aspek terminologis-historis dan (2) Aspek fungsional-praksis.

Pertama Aspek terminologi-historis. Istilah yang memisahkan antara Ulama dan Intelektual dapat ditelusuri dalam sejarah Ilmu Pengetahuan sejak dimulainya Abad Modern oleh Renaissance. Yang mengisyaratkan lahirnya humansime sekuler bersamaan dengan upaya mendewa-dewakan rasionalitas, sehingga begitu menekankan peran manusia-namun perlahan tapi pasti-menafikkan dogma-dogma agama, bahkan Tuhan. ${ }^{8}$ Dikotomi ilmu ini tidak sepenuhnya keliru jika keduanya saling mengisi. Namun menjadi masalah jika terjadi pertentangan di antara keduanya. Sehingga melahirkan asumsi-asumsi irrasional yang mengatakan, bahwa hanya dengan mempelajari ilmu agama saja yang akan mengantarkan manusia ke surga, adapun bagi yang mempelajari ilmu dunia justru akan menjerumuskan diri ke dalam neraka. Atau isu tentang Ilmu dunia adalah milik kaum penjajah, sementara ilmu agama adalah milik umat Islam. ${ }^{9}$

Pemahaman demikian ikut mengerucutkan pengertian ulama hanya kepada orang-orang yang pandai ilmu akhirat saja, sementara orang-orang yang mempelajari ilmu matematika, astronomi, fisika, kimia dan ilmu dunia lainnya, bukanlah ulama, namun cukup "intelektual” atau "Sarjana" (suatu penggolongan istilah yang sulit ditemukan dalam lembar sejarah intelektual Islam masa silam). ${ }^{10}$ Dikotomi ini ternyata berpengaruh besar pada motivasi umat

\footnotetext{
${ }_{7}$ Pendidikan dan IImu pengetahuan Muslim abad pertengahan didukung oleh spirit skolastikisme, tidak seperti pada ilmu pengetahuan dan Pendidikan Barat (yang bahkan menafikan doktrin agama, red). Para ilmuwan muslim berusaha mempertemukan pemikiran Greco-helenistik dengan doktrin religius muslim, yang mencapai puncaknya pada masa al-Ghazali. Baik dalam pola pendidikan, pengetahuan skolastik, logika dan metode, kesemuanya dilakukan untuk mempertemukan pengetahuan sekular dengan dogma religius, untuk menyelaraskan akal dan agama. Lihat Mehdi Nakosteen, H istory of Islamic O rigins of Western Education (terj), (Surabaya, Risalah G usti, 1996), h.xi ${ }^{8}$ Kuntowijoyo, Paradigma Islam (Bandung, Mizan, 1991), 160.

${ }^{9}$ Secara historis. pembedaan ilmu ini dapat ditelusuri pada sejarah perjuangan ulama Indonesia di zaman penjajahan B elanda. Diawali oleh sikap non-kooperatif (bahkan isolatif) para ulama terhadap segala "itikad baik" Belanda yang ingin menyertakan rakyat " $\mathrm{H}$ india Belanda" dalam peradaban modern (eropa) dengan pendidikan sekulernya. Para ulama kemudian mengimbanginya dengan mendirikan pesantren-pesantren yang mentradisikan zawiyah dan ribat(seperti di India dan Timur Tengah), dan selanjutnya "mengharamkan" segala yang berasal dari Barat, termasuk model pendidikannya. lihat N urcholish Madjid, Islam Doktrin dan Peradaban (J akarta: Yayasan Wakaf Paramadina,1992), ivii.

${ }^{10}$ Di masa Dinasti A bbasiyah, gelar hakim atau hukama' belum dapat disandang seorang jika hanya menguasai salah satu cabang ilmu pengetahuan saja. $\mathrm{H}$ al ini dikarenakan pada masa itu ilmu pengetahuan belum terpecah-
} 
Islam dalam mengkaji ilmu yang diminatinya. J ika ia hanya berminat menekuni ilmu-ilmu agama untuk nantinya menjadi ulama, maka cukup pesantren dan madrasah-madrasahlah tempatnya. Sementara bagi yang ingin mempelajari ilmu dunia untuk menjadi seorang intelektual, maka sekolah dan universitas jalurnya.

Kedua, aspek fungsional Ulama dan Intelektual dalam kehidupan praksisnya. Oleh karena image Ulama adalah orang yang ahli dalam ilmu agama, yang bisa ditemui di pesantren dan madrasah-madrasah, maka tugas dan fungsi Ulama juga berada di masyarakat-masyarakat santri, di desa-desa, berdakwah untuk orang-orang pinggiran dan terbelakang, bahkan kadang tanpa bayaran sepeserpun. Sementara bagi para intelektual yang lulusan universitas, tugas dan fungsinya untuk masyarakat-masyarakat berkelas, di kota-kota, "berdakwah" di kampuskampus dan di hotel-hotel mewah nan megah dengan bayaran yang cukup tinggi. Bagi kalangan apologetik, keadaan ini dianggap wajar dan lumrah, karena jika dibandingkan, "ongkos" menuntut ilmu agama di pesantren tentu tak sebanding dengan menuntut ilmu umum yang harus merogoh kocek mahal sampai ke S-3?!

Tanpa disadari, fakta di atas merupakan bentuk pengerdilan arti dakwah dari makna hakikinya. Dan lebih mendasar lagi adalah pendistorsian ilmu itu sendiri.

\section{c. Paradoks Pribadi Muslim}

Efek negatif lain dari derasnya arus pemikiran Barat dalam paradigma muslim adalah lahirnya pribadi-pribadi yang paradoks, yang menurut istilah $\mathrm{H}$ aedar $\mathrm{N}$ ashir, penuh dengan "pesona keagamaan". ${ }^{11}$ Tampaknya refleksi yang disampaikan patut kita cermati dalam konteks keberagaman masa kini.

Menurut Haedar, di zaman modern ini-atau lebih tepatnya zaman postmodernternyata tak mudah menjadi orang Islam yang baik. A palagi menjadi Muslim yang kaffah, atau cerdas dan cerah diri. Ilmu agama mungkin seluas samudera, namun praktik beragama tak semudah dikata. Maka terjadilah paradoks dalam ucapan yang tak seindah tindakan.

Sebagaimana ragam sajian keagamaan yang begitu semerbak, disuguhi penuh pesona dan mengharu-biru. Seakan menghipnotis umat untuk masuk dalam arena keagamaan populer. Dan menampilkan agama yang ringan dan menyenangkan, dan begitu memikat publik, sekaligus menjadi magnet para pemilik modal di dunia pasar.

Agama tampil begitu sarat simbolisme. Seperti dzikir berjamaah, Manajemen Q albu, Tabligh Akbar. Semuanya penuh dengan warna verbalisme. Umat dijadikan semakin bergairah dan penuh kesyahduan. Meskipun tetap diakui Haedar, hal itu merupakan modal penting

pecah. Sehingga motif kajian ilmu pengetahuan, khususnya filsafat, astronomi, kedokteran clan sejarah adalah untuk menjelaskan tentang keberadaan Tuhan. Jasa terbesar yang dilakukan oleh para hukama ini adalah menempatkan filsafat dan agama pada satu perbatasan dan filsafat dengan ilmu kedokteran pada perbatasan yang lain. Dalam perjalanan waktu, mereka yang membahas semua masalah yang tidak terbatas pada agama saja dinamakan Failasuf, sementara yang membahas filsafat namun dalam ruang lingkup agama dinamakan mutakallimin atau ahl kalam. Lihat, Nurcholish Madjid, Islam Doktrin dan Peradaban 201-203. Lihat juga Harun Nasution dan Azyumardi Azra (ed.), Perkembangan Modern dalam Islam (J akarta: Obor, 1985), 8-11.

${ }^{11}$ Haedar Nashir, Pesona Keagamaan (artikel), Republika, Desember 2006. 
yang sangat positif bagi umat. Sebab, dengan Islam yang tampil simbolik, shari'ah, dan spiritual maka ada bangunan elementer yang menjadi tumpuan. Ada tiang-tiang penyangga sekaligus penyelamat aqidah Islamiyah.

Namun cukupkah verbalisme dalam beragama? Ternyata tidak, sebab ajaran serba simbol ini masih membutuhkan ajaran lain dari dunia makna-yang juga sama pentingnya. Verbalisme dan simbolisme akan menghentikan langkah kita hanya pada tataran rukun semata, pada simpul-simpul harfiah. Yang asalkan rukun sudah terpenuhi, maka ajaran tertunaikan hingga di situ. Tidak lagi dipersoalkan bagaimana makna dan fungsi sạlat secara lebih mendalam. J ika demikian, maka jurang antara simbol dan makna yang akan semakin menganga. Sebab shalat pada hakekatnya bertujuan antara lain untuk menciptakan komunikasi antara hamba dengan Tuhan-nya. ${ }^{12}$

J ika keberagamaan hanya pesona, maka fenomena orang berdakwah di TV juga sekedar menjadi komoditi untuk menghibur (entertaint) para penikmat TV, dan media massa lainnya. Meski tentu saja ada baiknya manfaatnya, tetapi jangan terkejut jika saat media telah dicela. Sebab, menuruut J ohn Storey (pakar budaya), meskipun TV (atau media-media lainnya) memiliki kecanggihan semiotik permainan intertekstual dan elektisisme radikalnya, ia sering dicela sebagai lembaga komersial yang sia-sia. ${ }^{13}$ Maka figur panutan dan idola pun akan menjadi cemoohan.

Verbalisme lain juga ditampilkan dari para kaum Liberal-naif. Teks ajaran serba didekonstruksi dengan nalar positivis Gramscian. Ajaran agama selalu dicurigai memiliki ideologi hegemoni, seolah kehilangan daya autentisitasnya atau kehilangan fungsi sakralnya. Meski terus meneriakkan perlawanan keras terhadap bentuk-bentuk ekstrem dari pemeluk agama. Padahal yang mereka lakukan adalah bentuk lain dari ekstremitas, yaitu Nihilisme agama. Karena pada saat yang sama demokrasi, H AM, dan rasionalisme positivis didewakan seolah jadi agama baru. Ambivalensi ini merupakan karakteristik manusia modern, yang meskipun telah dapat lepas dari belenggu pemikiran mistis, namun ternyata tidak mampu melepaskan diri dari belenggu lain, yaitu penyembahan pada dirinya sendiri. ${ }^{14}$

Agama dan keberagamaan kemudian kehilangan daya pencerahan. Agama menjadi kehilangan alternatif dari hiruk-pikuk serba ekstrem dan radikal. Para elite Muslim kehilangan energi aktualnya dalam mencari solusi bagi problem rumitkemanusiaan. Yang muncul sekedar pesona Islam, namun kehilangan makna substantif. Islam tampak tangguh, tetapi sebatas kegagahan konservatisme. Islam disuarakan kaffah, sempurna dan utuh tetapi yang muncul hanyalah potongan-potongan hampa. Demikian gambaran pribadi muslim masa kini.

\section{d. Tuduhan Teroris}

Salah satu problem serius yang juga dihadapi muslim modern adalah image teroris yang dengan intens digembar-gemborkan Amerika dan sekutunya kepada Islam. Seakan Islam begitu

\footnotetext{
${ }^{12}$ Syaikh J alal Muhammad Syafi'i, The Power of Shalat ( Bandung, 2006), 68.

${ }^{13}$ J ohn Storey, an Introduction Guide to Cultural Theory and Popular Culture (terj) (Yogyakarta: Q alam, 2003), 264.

${ }^{14}$ Kuntowijoyo, Paradigma Islam (B andung, Mizan, 1991), 159.
} 
identik dengan kekerasan. Doktrin yang penuh dengan ajaran kebencian terhadap Barat.

Pada saat yang sama, di berbagai belahan dunia Islam menampakkan karakteristik yang sangat memilukan. Pertama miskin, kedua terbelakang, dan ketiga diliputi ketidakadilan. Yang terakhir, inilah yang sering memicu konflik internal di negara-negara Islam sehingga mengakibatkan banyak pemerintahan Islam bersikap totaliter. Beberapa negara di Timur Tengah justru dikenal sebagai negara-negara yang tidak mengedepankan keadilan dalam pemerintahannya. ${ }^{15}$ Lengkap sudah penderitaan umat Islam, di satu sisi ingin menghadapi serangan ideologis dengan cap terorisnya, namun di sisi lain justru tidak menampakkan kondisi yang memadai dari sebuah peradaban yang tinggi.

Bila dicermati, sikap fobia terhadap Islam dan umatnya mungkin dapat dirujuk pada teori-teori yang disusun dan dikembangkan berdasarkan asumsi institusional, antara lain teori "benturan peradaban" atau Clash of Civilization yang dikemukakan beberapa tahun lalu oleh Samuel Huntington, seorang guru besar di Harvard University. Menurut konsep itu, peradaban Islam lambat laun akan berbenturan dengan peradaban dunia lainnya akibat perbedaan karakteristinya dengan (Islam). ${ }^{16}$

Tesis ini kemudian memberi pengaruh besar bagi kebijakan Eropa-Barat terhadap Islam. Merubah secara drastis cara pandang B arat tentang Islam, mengendap dalam segala bentuk pemikiran dan sikap, dan menjelma menjadi ketakutan yang berlebihan, rasa curiga dan antipati terhadap segala hal yang berkaitan dengan simbol-simbol keislaman. Sikap Barat ini seakan menemukan momentumnya saat peristiwa 9/11 terjadi. Maka lahirlah (baca: dilahirkan?) terorisme Islam. Sejak saat itu, tak ada lagi "ruang yang nyaman" bagi kelompokkelompok, maupun pribadi-pribadi yang dianggap - terlebih dahulu dicap-teroris. Semua yang masuk daftar teroris kemudian dihubungkan dengan jaringan Al-Q aeda, atau J amaah Islamiyah, yang sebagian besar masih menggantung tanpa fakta.

Padahal, jika menggunakan logika sebab-akibat, sepatutnya AS menyadari dan mampu memahami lebih jauh, mengapa sampai terjadinya gerakan teroris? Bukankah munculnya akibat pasti ada penyebabnya? Bagaimana mungkin AS yang mengagungkan logika tak mampu berpikir logis?!

Alhasil, berdasarkan tesis Huntington, Islam dan umatnya tak akan mampu bertahan lama, jika masih saja resisten terhadap peradaban Barat-Modern. Sebab, umat Islam tidak punya pilihan lain kecuali mengadopsi kultur dan budaya Barat agar dapat menjaga eksistensinya di tengah menguatnya dominasi peradaban Barat.

Namun, tesis Huntington ternyata ada 'celah' nya. Atau dapat dikatakan luput dari perkembangan sejarah yang sebenarnya, bahwa ada ratusan ribu orang pemuda muslim, mengambil ilmu-ilmu eksakta dan teknologi mutakhir dari Barat. Tentu mereka juga paling tidak "menyerap" peradaban dan budaya Barat. Walaupun sudah tentu yang diambil hanyalah sebagian kecil dari peradaban itu sendiri. Hal demikian ternyata tidak menjadikan mereka harus berkonfrontasi dengan kebudayaan Barat itu, jadi mengapa harus khawatir terhadap

${ }^{15}$ Lihat artikel Dilema Dunia Islam oleh M. Bambang Pranowo Guru Besar Sosiologi Agama UIN Ciputat, Tempo, 16 Maret 2007

${ }^{16}$ Samuel P. Huntington, Clash of Civilization (terj. ), (Yogyakarta: Q alam, 2002), 605. 
"tantangan Barat?"

Bahkan, kini Barat tengah berada dalam kebingungan besar akibat ketidakmampuannya dalam menghadapi kebangkitan kembali agama-agama di abad modern. Dalam laporan terakhir dari The Economist, sebuah majalah yang terbit di New York, edisi November lalu, mengangkat sebuah tajuk berjudul "The New Wars of Religion", menyimpulkan, agama tidak akan surut apalagi mati karena modernisasi dan sekularisasi. Terhitung sejak 1970-an agama ternyata mampu kembali ke pentas berbagai lapangan kehidupan, termasuk politik, sosial, budaya, ekonomi dan seterusnya. Dan pada tahun 2005 sekitar 73 persen umat manusia di seluruh dunia memeluk salah satu agama dari empat agama besar; Kristen, Islam, Hindu, dan Budha dan menurut prediksi akan meningkat $80 \%$ pada $2050 .{ }^{17}$

\section{e. Problem Mayoritas-Minoritas}

Problematika mayor-minor dalam suatu komunitas menjadi semakin marak beberapa tahun belakangan, tanpa diketahui persis apa penyebabnya dan kapan munculnya. Ukuran mayoritas-minoritas ternyata masih menggantung. Pada hitungan jumlah? Perbedaan warna kulit? Perbedaan keyakinan? Perbedaan agama? Perbedaan suku, dan adat-istiadat? Atau perbedaan kepemilikan modal? J ika semua itu dijadikan ukuran, maka arti mayor-minor menjadi sangat relatif?! Karena, boleh jadi di satu tempat golongan minoritas dapat menjadi komunitas mayoritas di tempat lain, atau sebaliknya.

Pada kenyataannya, di banyak negara berpenduduk muslim masih sering terjadi konflik mayoritas-minoritasini. Iraq, yang berhadapan dengan Kurdistan (1984), India dengan Kashmir (1970), Turkey dengan suku Kurdi (1984), Russia dengan Chechen (1992), perang saudara di Sudan (1983), Philippines dengan Moro (1970), perang saudara di Uganda (1980), Konflik di Iraq antara Sunni-Syi'ah (sekarang), konflik antara Sunni-Syi'ah di Pakistan dan pertempuran melawan gerilyawan Al-Q aeda dan eks Taliban (2002-sekarang), Mayoritas Islam dengan kelompok sekuler Turki (sampai sekarang), konflik etnis antara pemerintah dan kelompok minoritas Tamil di Sri Lanka, (2002), konflik Muslim mayor dan non Muslim minor tentang peninjauan ulang terhadap Undang-Undang Dasar Malaysia. ${ }^{18}$ Begitu pula di Indonesia, yang sampai saat ini masih dihadapkan dengan persoalan tuntutan merdeka kelompok minor di Papua, dan Ambon.

Mengapa harus terjadi dikotomi antara keduanya? Mungkin pertanyaan ini sangat relvan dengan problem yang dihadapi masyarakat dunia saat ini. Apakah dengan menjadi minoritas berarti harus siap dipojokkan, atau bahkan tidak dianggap sama sekali? Ataukah sebagai kelompok mayoritas dapat sesuka hati berkuasa dan menindas?

Padahal, jika diamati dunia ini justru lebih sering dikuasai oleh golongan minoritas. Lihat saja bagaimana Dewan Keamanan PBB yang hanya terdiri dari sejumlah kecil negara mampu "mewakili" hak ratusan negara anggotanya melalui hak veto? Atau bagaimana negara kecil Yahudi dapat dengan mudah menyetir negara adidaya Amerika Serikat? Atau bagaimana

17 Lihat Azyumardi Azra, Perang Baru Agama (artikel), Republika, 2007

${ }^{18}$ Dari berbagai sumber: wikipedia.org, Faith Freedom International-Forum Indonesia.org, Serambi Indonesia.com, Pikiran Rakyat Cyber Media, Radio Singaphore International online, 2003 
segelintir "orang J akarta" mampu membuat ratusan juta rakyat Indonesia sakit kepala begitu mendengar kenaikan tarif harga BBM?

Faktanya, dikotomi mayoritas-minoritas terbukti sering dipakai sebagai pendekatan yang strategis untuk memprovokasi masyarakat plural seperti Indonesia. Lalu semua orang menjadi sibuk memperdebatkan segala macam isu tentang penekanan kaum mayoritas terhadap kaum minoritas, sehingga substansi yang tersimpan di balik tujuan-yang seringkali hanya menguntungkan pihak tertentu - dapat tercapai.

Tampaknya kita umat Islam terlalu serius menyikapi alfabeta perbedaan, sehingga membuat kita lupa, bahwa sesungguhnya kita begitu kaya karena banyak perbedaan.

f. Kemiskinan Struktural

Berdasarkan fakta-fakta yang ada, mayoritasumat Islam hidup dalam kemiskinan. Tidak perlu kita pungkiri, sebab yang harus dipikirkan adalah bagaimana cara kita menerima kenyataan ini dengan positif, meskipun begitu pahit.

Pembaharu Islam, J amaluddin al-Afghani, seringkali mengutip $H$ dith Nabi yang berbunyi al-Islam ya'lu walayu'la>alayh (Islam itu unggul dan tidak ada yang mengungguli Islam). $\mathrm{H}$ dith tersebut sampai kini sering dikumandangkan para pemimpin Islam di dunia ketika berbicara di forum-forum internasional. Namun, jika kita lihat realitas kehidupan umat di negeri-negeri Muslim tampak jelas kondisi umat Islam jauh dari posisi 'unggul' tersebut.

Kenapa negara-negara Islam miskin? Ini satu persoalan yang tidak mudah dipecahkan. Karena pada kenyataannya, 75 persen sumber minyak bumi dunia berada di 'perut' negaranegara Islam atau berpenduduk mayoritas Islam. Tapi nasib penduduk/umat Islam sendiri amat memprihatinkan. Dari data lain ditemukan, 24 persen penduduk Islam Dunia berpendapatan kurang dari $\$ 1$ US per hari, 39 persen hidup di bawah garis kemiskinan dan 45 negara Organisasi Konfrensi Islam (OKI) mempunyai penduduk berpendapatan tahunan kurang daripada $\$ 1,000$ US. ${ }^{19}$

Yang mengherankan, 70 persen pemasok tenaga kerja dan 40 persen hasil ekspor bahan mentah dunia justru berasal dari negara Islam. Bagaimana mungkin dengan potensi yang luar biasa seperti ini masih belum dapat memajukan umat Islam? Bukankah dengan kekayaan ini seharusnya mampu membuat negara-negara Islam berpotensi lepas dari pada jeratan kemiskinan. Apa penyebabnya?

Salah satunya adalah tidak terdistribusikannya kekayaan negara terhadap penduduk secara adil. Tidak adanya transparansi dan sistem pemerintahannya yang adil, sehingga menjadikan kekayaan negara hanya dinikmati kelompok elite tertentu. Dalam perspektif Marxian, problem ini bukan hanya melahirkan kemiskinan yang berkepanjangan, namun juga akan mengakibatkan instabilitas sosial yang berujung konflik. ${ }^{20}$ Konflik itu disebabkan adanya perbedaan yang signifikan dalam perolehan sumber-sumber yang bernilai, di antara

${ }^{19}$ Dikutip dari statemen Menteri Keuangan Kedua Malaysia, Tan Sri Nor Mohamed Yakcop, lihat di www.WordPress.com

${ }^{20}$ Doyle Paul J ohnson, Sociological Theory (terj) (J akarta : Gramedia, 1986), 217. 
kepentingan-kepentingan yang bertentangan.

Kesalahan lain terletak pada persepsi, yang umumnya mengkategorikan suatu negara miskin, karena negara tersebut tidak bermodal. Karenanya dibentuklah Badan Keuangan International IMF atau sistem Bretton Wood yang terkenal itu untuk melakukan suntikan modal, diharapkan agar dapat memperkaya negara-negara tersebut. $\mathrm{H}$ al ini jelas menjanjikan keuntungan struktural kaum kapitalis (seperti AS) untuk melebarkan hegemoni-nya, meskipun harus melanggar otonomi negara dalam menjalankan kebijkan-kebijakan ekonomi domestik, khususnya terhadap negara-negara defisit. ${ }^{21} \mathrm{~N}$ egara-negara berkembang tentu tidak akan dapat bergerak leluasa akibat terperangkap dalam jerat hutang yang terus "mencekik". Hal ini pada akhirnya dapat melahirkan kemiskinan struktural yang berkepanjangan bagi negara tersebut.

Karena itu, upaya untuk menginovasi perdagangan di kalangan negara Islam memerlukan daya intelektual, tokoh pemikir, cendekiawan, para ulama, dan saintis yang berpikiran kreatif dan holistik.

\section{Islam dan Strategi Masa Depan}

Bukan suatu hal yang mudah untuk melahirkan sebuah pemikiran pembaharuan, apalagi merumuskannya ke dalam langkah-langkah strategis bagi pembenahan kondisi umat saat ini. Namun tentu bukan menjadi penghalang bagi kita umat Islam untuk berpikir dan bertindak bersama-sama mewujudkan masyarakat Islam yang maju, mulai saat ini.

Mengacu pada prinsip al-Qur'an, "Dan masa (kejayaan dan kehancuran) kami (Allah) pergilirkan di antara manusia (agar mereka mendapat pelajaran)" (QS. 3:140), sepatutnya dibaca dalam satu tarikan nafas bersamaan dengan semangat untuk kebangkitan Islam di masa depan. Kejayaan yang dialami peradaban Barat saat ini, sesungguhnya menuju kepada kehancuran, dengan gejala yang kian nampak jelas berupa kesombongan (baca: kezaliman) yang dipamerkan kepada dunia. Inilah momentum tepat bagi kebangkitan umat Islam, dan menjawab segala tantangan yang ada di hadapannya untuk bersaing menjadi kekuatan penyeimbang dari peradaban Barat-Modern. Teori Huntington dengan "benturan peradaban" seharusnya dibaca dalam konteks ini.

Yusuf Qardhawi menggunakan istilah "Siklus Peradababan" dan masa depan siklus itu akan menjadi milik umat Islam. ${ }^{22}$ Sementara H asan H anafi menggunakan teori: U mat Islam berada di antara dua masa yang membingungkan; masa berakhirnya peradaban Barat yang belum habis dan masa kejayaan Islam yang belum tiba. Lengkap sudah referensi kita untuk memanfaatkan nya sebagai momen kebangkitan Islam.

Namun hemat kami, masa kejayaan Islam itu akan terlambat tiba, karena kita sedang terjebak dalam sebuah sistem tata dunia yang "diatur" oleh tangan-tangan adidaya yang angkuh, zalim dan tidak bermoral. Sadar atau tidak, sistem demokrasi yang kita anut saat ini adalah salah satu bukti keterjebakan kita dari bujuk rayuan Barat. Padahal kita tahu, sistem demokrasi Barat tidak sama dengan konsepsi Islam tentang musyawarah seperti yang dijelaskan dalam al-Q ur'an:

${ }^{21}$ Antonio G ramschi, Restructuring H egemony and the Changing Discourse of Development (terj.) dalam Muhadi Sugiono, Kritik Pembangunan Dunia Ketiga (Yogyakarta, Pustaka Pelajar, 1999), 65.

22 Yusuf Q ardhawi: U mmatuna Baina Q arnaini (Dar al-Shuruq, Kairo, 2000) 


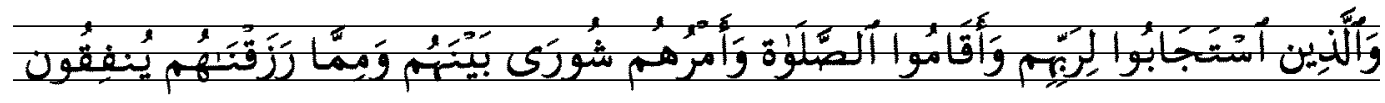

“Dan (bagi) orang-orang yang menerima (mematuhi) seruan Tuhannya dan mendirikan sălat, sedang urusan mereka (diputuskan) dengan musyawarah antara mereka; dan mereka menafkahkan sebagian dari rezki yang Kami berikan kepada mereka" (QS. 42:38).

Sebaliknya, 'cara bermusyawarah' dalam sistem demokrasi adalah sebuah pemaksaan mayoritas, atau bisa jadi diktator minoritas.

Sementara itu, pada sektor ekonomi-perdagangan dan investasi masih jauh dari harapan. Belum lagi intervensi para adidaya terhadap keputusan-keputusan strategis organisasi-organisasi Islam di tingkat internasional. Wajar jika eksistensi Organisasi Konferensi Islam (OKI) terus dipertanyakan.

Oleh karena itu, dalam menata strategi masa depan, umat Islam harus mampu membangun dirinya secara komprehensif melalui empat hal:

Pertama, umat Islam harus berakhlak dengan akhlaq al-Qur'aß. Ini pondasi yang harus sejak awal dibangun. J ika dunia Barat maju dengan meninggalkan agama mereka. Maka umat Islam hanya bisa maju apabila konsekwen dengan agamanya. Ingatkah kita tentang runtuhnya peradaban emas Islam 8 abad lampau, yang kenyataannya disebabkan oleh kemerosotan akhlak para pemimpinnya. ${ }^{23}$

Satu hal yang penting dicermati, bahwa dari semua peradaban yang datang dan pergi, dan kejayaan-kejayaan yang pernah menjulang tinggi lalu sirna, Islam dengan pedoman alQur'an dan $\mathrm{H}$ ddith tetap mampu bertahan dan dapat berfungsi sebagai kekuatan pemersatu (unifying force) yang tidak dimiliki peradaban lain. ${ }^{24}$

Meskipun pada sisi lain, potensi (pemersatu) yang hendak diwujudkan itu seringkali terbentur dengan kenyataan yang ada, sehingga menjadikan kemajuan umat Islam yang hendak dicapai menjadi terhambat (dihambat?) oleh 'kemilau'nya tawaran-tawaran Barat Modern. Namun di sinilah kesungguhan kita diuji, mampukah kita menggali kekayaan intelektual sendiri? Karena tentunya lebih relevan dengan cara pandang kita sebagai umat Islam, untuk kemajuan yang lebih beradab.

Kedua, Sinergi antara Sumber Daya Manusia (SDM) dan Sumber Daya Alam (SDA). Dengan rahmat Allah Swt., mayoritas wilayah yang dihuni umat Islam tersimpan potensi dan deposit (SDA) yang sangat kaya di alam ini.

Sosiolog dan sejarawan Muslim legendaris Ibnu Khaldun dalam karya Muqaddimahnya mengatakan, bahwa posisi geografis dan kondisi ekologis merupakan keunggulan sekaligus kunci sukses imperium Islam dahulu. ${ }^{25}$ Sejalan dengan hal ini, J effrey Sachs (2005) membagi kawasan

\footnotetext{
${ }^{23}$ Di akhir masa kejayaannya selama 90 tahun, Dinasti Umayyah telah mengesampingkan prinsip-prinsip pemilihan. Republikanisme diganti dengan monarki turun temurun, dengan diangkatnya Yazid sebagai putra mahkota. Diantara para khalifahnya lemah dan tidak lagi cakap dalam kepemimpinannya, bahkan terjerumus kedalam tindakantindakan amoral. Kondisi serupa terjadi pada Dinasti Abbasiyah setanjutnya, di akhir kepemimpinan gemilang alWatiq, tidak seorangpun dari ke dua puluh tujuh khatifah selanjutnya yang cakap. Lihat Syed Mahmudunnasir, Islam: Its concepts \& History (terj.) (B havan:N ew Derlhi, 1981), 239-240 \& 279-281.

${ }^{24}$ Gustave E. Von Grunebaum, Kesatuan dan Keseragaman (J akarta: Obor, 1983), 21-39.

${ }^{25}$ Ibnu Khaldun, Abdul Rahman, Muqaddimah (Kairo: Dar Ihya' al-Kutub al-Arabiah, 1960)
} 
dunia Islam berdasarkan potensi ekonomi menjadi enam wilayah, yaitu; Afrika Utara, sub-Sahara Afrika, Timur Tengah, Asia Tengah, Asia Selatan, dan Asia Tenggara. ${ }^{26}$ Wilayah-wilayah ini sesungguhnya menyimpan potensi ekonomi sangat kaya, namun potensi dan deposit yang kaya itu belum dapat diimbangi dengan ketersediaan SDM yang handal, di samping bantuan investasi dasar di bidang produksi dan pengembangan industri, tentunya.

Namun akibat ketidakberdayaan umat muslim, mereka layaknya tamu di negeri sendiri, atau bahkan ibarat tikus mati di lumbung padi. Karena potensi alam melimpah ruah yang tak mampu diolah, justru dimanfaatkan pihak asing, sementara sebagian besar rakyatnya yang muslim, harus rela menjadi buruh-buruh pabrik, pekerja-pekerja kasar proyek bangunan, yang terus-menerus hidup dalam kemiskinan.

Fenomena ini mengharuskan kita untuk melakukan peninjauan ulang terhadap peran ilmuan muslim saat ini. Reaktualisasi peran para ilmuwan yang dimaksud harus diawali dari pembenahan paradigma mereka terhadap ilmu itu sendiri. Yaitu ilmu yang berakar dari khazanah keislaman, yang bersandarkan al-Q ur'an dan al-H dith sebagai pedoman hidup. Reaktualisasi peran bukan lagi semata-mata pada perumusan kebijakan strategis dalam pengembangan sains dan teknologi-apalagi dengan mengacu pada pertumbuhan ekonomi yang dihasilkan BaratAlih-alih menjadikan ilmuan muslim yang berkualitas, peran ilmuan bisa jadi tanpa makna, karena terjerembab dalam kubangan materialisme dan sekulerisme ala Barat.

Sebaliknya, ilmu yang dipahami dengan cara pandang Islam akan melahirkan pribadi muslim yang cerah diri, bersih jiwa dan pikirannya. Yang tertanam di dalamnya rasa cinta akan kebaikan dan keadilan. Dan yang dapat mendatangkan ketenangan dan ketentraman jiwa dan hatinya. Bukan ilmu yang menimbulkan rasa curiga, dan melahirkan cara pandang yang berat sebelah (tidak adil), dan akhirnya berujung pada relativitas kebenaran ilmu, yang tentunya jauh dari tujuan ilmu itu sendiri.

Islam kini butuh seorang ilmuwan yang konsisten terhadap aqidah dan kepeduliannya terhadap umat. Ilmuwan yang benar-benar memahami arti penting sebuah pengamalan, dimana perbuatannya lebih banyak dari pada ucapannya. Dan ilmuwan yang berdaya guna bagi kemaslahatan umat dan kemajuan umat Islam, sebagaimana yang pernah dicapai peradaban Islam dahulu.

Ketiga, Penegakkan prinsip dan aturan Shariłat Islam. Upaya ini harus diawali dengan keyakinan yang kuat tentang siklus masa depan yang tertumpu pada umat Islam. Keyakinan ini bukan sekedar berasal dari kumpulan semangat yang berkoar-koar, tapi keyakinan yang bersumber pada al-Q ur'an. Sebagaimana diisyaratkan dalam surat al-Anbiyasayat 105-108:

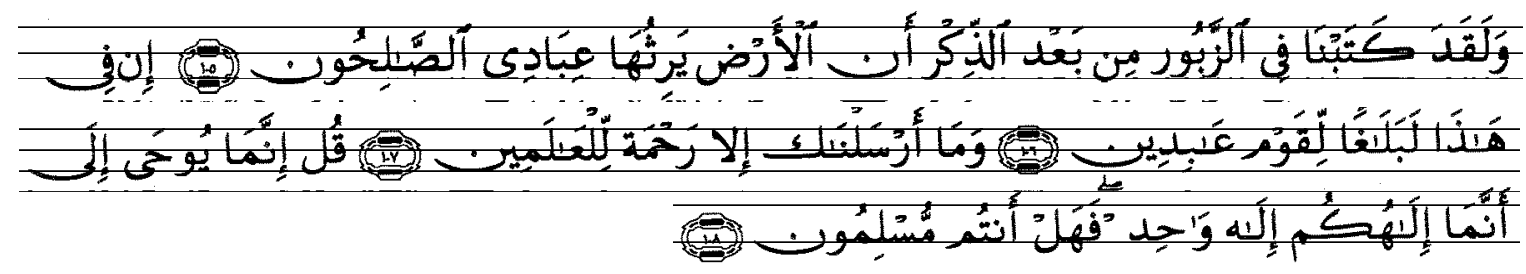

“Dan sungguh telah Kami tulis di dalam Zabur sesudah (Kami tulis dalam) Lauh Mahfuzh, bahwasanya bumi ini dipusakai hamba-hambaKu yang saleh. Sesungguhnya (apa yang

${ }^{26}$ Amich Alhumami, M engejar Kemajuan Barat (artikel) (J akarta: Republika, J uli 2007) 
disebutkan) dalam (surat) ini, benar-benar menjadi peringatan bagi kaum yang menyembah (Allah). Dan Tiadalah Kami mengutus kamu, melainkan untuk (menjadi) rahmat bagi semesta alam. Katakanlah: "Sesungguhnya yang diwahyukan kepadaku adalah: "Bahwasanya Tuhanmu adalah Tuhan yang Esa. Maka hendaklah kamu berserah diri (kepada-Nya)". (QS. Al-Anbiyas:105-108).

"Rahmat untuk semua alam" akan dirasakan bila masa lalu, sekarang dan yang akan datang ditegakkan dengan Shariłat Islam. Semua peradaban hanya dapat dipelihara dan dilindungi dengan ajaran Islam. Dengan penegakkan prinsip Shariłat Islam, maka agama ini akan dapat terus bertahan. Karena itu, makin konsekwen/istiqamah umat Islam dengan keislamannya, maka makin survive umat Islam menuju masa depan yang gemilang.

Namun, penegakkan prinsip dan aturan Sharisah tidak serta merta dapat diterapkan secara formal oleh negara sebagai hukum dan kebijakan publik hanya karena alasan bahwa prinsip shari'ah adalah bagian daripada hukum Islam. Sebab ketika syariah masuk kedalam ranah institusi negara, maka yang ada sesungguhnya adalah kehendak politik negara, dan bukan 'kehendak' hukum Islam. ${ }^{27}$

Artinya, Shariłah Islam dimungkinkan menjadi bagian dari kebijakan publik, namun tanpa perlu "campur tangan negara" agar umat Islam benar-benar dapat menjalankan keyakinan islamnya secara sungguh-sungguh, sebagai bagian dari pada kewajiban beragama, bukan karena paksaan negara.

J ika praktek keberagamaan dalam menjalankan syariat Islam telah terkondisikan dengan baik (Favorable); yang melahirkan mentalitas yang islami dan umat yang istiqamah, maka institusionalisasi Shari at Islam menjadi mutlak diberlakukan. Karena disadari, bahwa negara sebagai lembaga politik tidak selamanya dapat bersikap netral dari kepentingan warga negaranya. Adapun perundangan dan kebijakan publik adalah merupakan cerminan dari keyakinan dan nilai-nilai warga negara, termasuk nilai-nilai agama.

Keempat, Menjalin Kerjasama Internasional. Dalam kehidupan global, mengharuskan kita menjalani kerjasama internasional secara intensif. Implikasi Islam sebagai rahmatan lil alamin meniscayakan saling kenal, dan toleran yang dijalin dalam bentuk kerjasama yang saling menguntungkan menuju masa depan yang islami, maju, dan bermartabat.

Wallahua'lam bi shawab

\section{Daftar Rujukan:}

Abul A'la al-Maududi. al-K hilafah wa al-Mulk (terj.) Dar al-Qalam, Kuwait, 1978 Abdul Karim Soroush. M enggugat O toritas Tradisi Agama. Bandung: Mizan Pustaka 2002. Abdullah Ahmed an-Naim. Islam dan Negara Sekular: Menegoisasikan Masa Depan Syariah. Bandung: Mizan, 2007. Abdul Muhsin Sholeh, Prof.Dr. Anta kam Tusaawy (terj.) Surabaya: Ajang Cipta, 1986.

${ }^{27}$ Abdullah Ahmed an-Naim, Islam dan Negara Sekular: Menegoisasikan Masa Depan Syariah, (Bandung: Mizan, 2007) 
Adian Husain \& Nuim Hidayat. Islam Liberal: Sejarah, Konsepsi, Penyimpangan, dan J awabannya. J akarta: GIP, 2002.

Amich Alhumami. Mengejar Kemajuan Barat (artikel) J akarta: Republika, J uli 2007.

Arnold Toynbee. A Study of History. London: Oxford University Press, 12 vol., 1934-1961.

Charles Kurzman (ed.). Wacana Islam Liberal, pemikiran Islam Kontemporer tentang isu-isu

Global. J akarta: Paramadina, 2001.

Doyle Paul J ohnson. Sociological Theory (terj) J akarta : Gramedia, 1986.

Fazlur Rahman. Islam: Challenges \& O pportunities, dalam Harun Nasution \& Azyumardi Azra

(ed.). Perkembangan Modern dalm Islam. J akarta: O bor, 1985.

Gustave E. Von Grunebaum. Kesatuan dan Keseragaman. J akarta: Obor, 1983.

H aedar Nashir. Pesona Keagmaan (artikel). Republika, Desember 2006.

H arun Nasution. Islam Ditinjau Dari Berbagai Aspeknya. UI Press, 1985.

Ibn Khaldun, Abdul Rahman. Muqaddimah. Kairoh: Dar Ihya' al-Kutub al-Arabiah, 1960.

J ohan H endrik Meuleman. Tradisi, kemodernan dan Metamodernisme. Yogyakarta: LKiS, 1996.

J ohn Storey. An Introduction G uide to Cultural Theory and Popular Culture (terj). Yogyakarta:

Qalam, 2003.

Leonard Binder. Islam Liberal. Yogyakarta: Pustaka Pelajar, 2001.

Kuntowijoyo. Paradigma Islam. Bandung, Mizan, 1991.

Mehdi Nakosteen. History of Islamic O rigins of western Education (terj). Surabaya, Risalah Gusti, 1996.

Montgomery Watt. The Majesty that was Islam (terj.). Yogyakarta, Tiara Wacana, 1990.

Mohammed Arkoun. Islam Kemarin dan Esok. Bandung: Pustaka, 1997.

Murtadha Muthahhari. Islam dan Tantangan Zaman. Bandung: Pustaka H idayah, 1996.

Malik bin Nabi. Membangun Dunia Baru Islam. Bandung, Mizan, 1994

Nurcholish Madjid. Islam Doktrin \& Peradaban. J akarta: Yayasan Wakaf Paramadina, 1992.

- - - . Khazanah Intelektual Islam. Bulan Bintang, J akarta, 1994.

- - - \& \& Azyumardi Azra. Perkembangan M odern dalam Islam. J akarta: O bor, 1985.

Al-Qur'an al-Karim. (lijami'i al-Maliki al-Fahd, li-tibał al-Mushaf al-Sharif, al-Madinah al-

Munawwarah)

Syed Mahmudunnasir. Islam: Its concepts \& History (terj.). Bhavan: New Derlhi, 1981.

Samuel P. Huntington. Clash of Civillization (terj.). Yogyakarta: Q alam, 2002.

Yusuf Q ardhawi. Ummatuna Baina Q arnaini. Dar al-Syuruq, Kairo, 2000.

\section{Site surf:}

www.wikipedia.org

www. Faith Freedom International-Forum Indonesia.org

ww.Serambi Indonesia.com

www.Pikiran Rakyat Cyber Media.com

www.Radio Singaphore International.com

www.WorldPress.com

ww.Republika online, 16 Maret 2007. 